\title{
Rice Crop Phenology Model to Monitor Rice Planting and Harvesting Time using Remote Sensing Approach
}

\author{
Hafidh Waldini ${ }^{1}$, Iqbal Putut Ash Shidiq ${ }^{1, *}$, Rokhmatuloh Rokhmatuloh ${ }^{1}$, and Supriatna \\ Supriatna ${ }^{1}$ \\ ${ }^{1}$ Department of Geography, Faculty of Mathematics and Natural Sciences, University of Indonesia, \\ 16424, Jawa Barat, Indonesia
}

\begin{abstract}
Abstract. Rice is one of the most significant food commodity products in Indonesia. The production of rice in 2019 reached 49.8 million tons. On a global scale, rice is consumed by half of the human population around the world. This study will support the development of sustainable natural resources management, which is an important thing to the realization of the Sustainable Development Goals in zero poverty and zero hunger. Remote sensing is a useful instrument to monitor natural resources. This study used Sentinel-2 imageries to extract rice phenology using vegetation indices (NDVI and NDWI), then acquired the planting and harvesting time using the temporal analysis. The NDVI value is showing a parabolic curve regarding the planting stage of the rice. The value of NDVI is high in the transplanting stage but decreases in the harvesting phase. Besides that, in the seedling and transplanting stage, NDWI has a higher value than NDVI. However, in tillering until the harvesting phase, NDWI has a similar characteristic but lower value than NDVI. Based on the spatial and temporal distribution of rice planting and harvesting date, it is known that climate is not a resistant factor, especially the irrigated rice field. Nevertheless, in the rainfed rice field, the planting time depends on climate conditions.
\end{abstract}

\section{Introduction}

As one of the primary food commodities, rice is consumed by half of the global population [1]. Throughout a year, 150 million hectares of the rice crop area will averagely produce 500 million tons of rice [2]. FAO argued that $90 \%$ of rice is planted and consumed by most Asian populations, with $60 \%$ are situated in South East Asia like Indonesia, Malaysia, and Vietnam [2]. In Indonesia, rice is the staple food commodity. The most significant production was found in 2019, with 49.8 million tons. However, the number of rice imports in Indonesia continuously increased, where the largest was found in 2018 (2.2 million tons) [3].

Rice comes from paddy, a grass plant with a cylindrical hollow trunk with a thin parallel leaf [4]. Based on location and water condition, IRRI classifies paddy within four classes, which are (i) irrigated rice field, (ii) lowland rainfed rice field, (iii) highland rainfed rice field,

\footnotetext{
*Corresponding author: iqbalputut@sci.ui.ac.id
} 
and (iv) flood-prone rice field [5]. Based on the growth period, it can be classified into three types, (i) short period usually in 100 - 120 days, (ii) middle period usually in 120-140 days, and (iii) long period with 160 days or more [6]. According to the stages of development, the paddy development is divided into vegetative, generative, and ripening. Vegetative stages are indicated from sprouts growth until panicle initiation, and it commonly occurs 50 until 60 days. The generative phase is determined from panicle initiation until heading, and it commonly occurs in 30 days. Lastly is the ripening stage [4].

Spatial data have played an important role in recent times [7] and to be planned with a quality planning program and quality spatial component [8]. As the United Nations (UN) Sustainable Development Goals support zero poverty and zero hunger, the development of sustainable natural resource management is essential. Particularly, when the global population is expected to reach nine million people in 2050, it will become a big challenge, especially for sustainable food security.

Remote sensing is an effective instrument for detecting changes in land-use or landcover [9]. It is labor effective compared to the more conventional terrestrial surveys [10]. Regarding the mapping process, rice has a specific spectral characteristic in the early stages of planting [1], and it keeps changing in every phase of the growing stages [11]. Therefore, information about the rice phenology is important when deciding the planting date, heading date, and harvesting date for every rice crop [12]. The advantages of phenological-based research are to give an understanding of how the plant will respond to the climate condition and providing the reference for further food production [13]. This study aims to observe the spatial and temporal distribution of rice planting time and analyze the harvesting time based on phenological data from remote sensing-based vegetation index (NDVI and NDWI) and also to provide a method for creating spatial data in agricultural aspect.

\section{Methods}

This study uses Sentinel 2 level 2 multispectral satellite with a moderate resolution with 10 x 10 meter spatial resolution with 24 images in total for 2019. The information on rice age and growth phase is extracted from the Normalized Difference Vegetation Index (NDVI) and Normalized Difference Water Index (NDWI) [14,15]. Sentinel 2 (2A and 2B) have five days revisit time, which is reliable for the agricultural monitoring project [16]. This study uses a binary thresholding method and fuzzy overlay for satellite images using ESA SNAP to get the rice planting and harvesting date.

\subsection{Study Area}

The study is conducted in Parakansalak sub-regency that located in $6^{\circ} 44^{\prime} 34.8^{\prime \prime}-6^{\circ} 49^{\prime}$ $40.8^{\prime \prime}$ South dan $106^{\circ} 39^{\prime} 54^{\prime \prime}-106^{\circ} 44^{\prime} 24$ " East. Relatively, the location is adjacents to Pamijahan sub-regency in the north, Cidahu sub-regency in the east, Bojonggenteng subregency in the south, and Kalapanunggal sub-regency in the west. The total area of Parakansalak is 5,571.45 hectares, with more than 600 hectares (12\%) are the irrigated rice crop area. The topography and slopes are varied between the low-land area (200 above msl) and the high-land area (more than 700 above msl).

There are three main irrigation channels in Parakansalak, which are Situ Sukarame, Cipamatutan, and Cinala. The Situ Sukarame is irrigating Lebaksari, Bojongasih, and some areas in Bojonglongok. The water source in Situ Sukarame is from a natural lake called Situ Sukarame, located in eastern Parakansalak village, the northern part of Lebaksari. The rice field irrigated by Cipamatutan is unique because the rice field is aligned linearly with the Cipamatutan river. Cipamatutan is irrigating Sukakersa, some area in Parakansalak, and some area in Bojonglongok, in the north-south direction of the sub-district. 


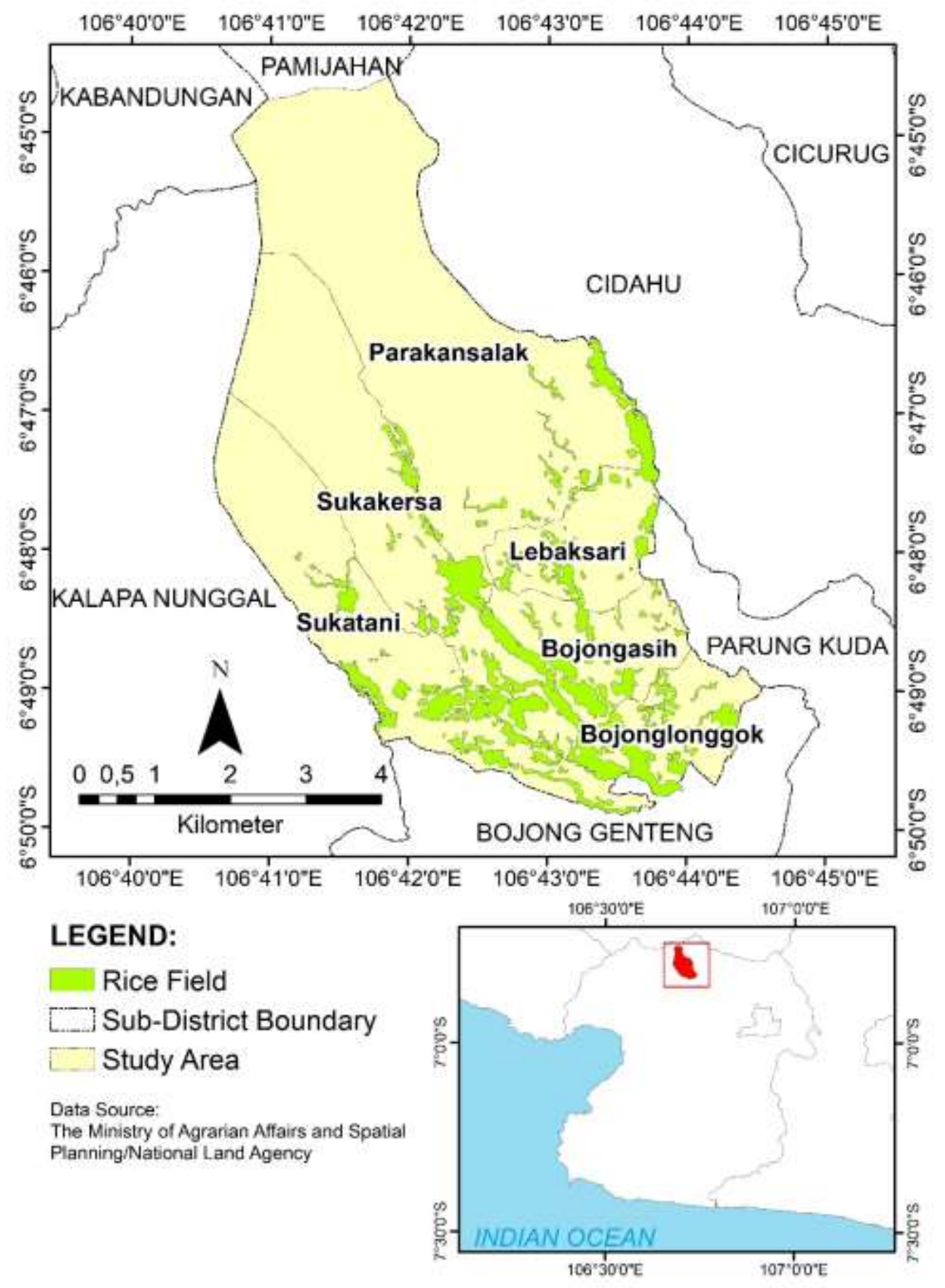

Fig. 1 Parakansalak Administration Maps 


\subsection{Image Acquisition}

\subsubsection{Sentinel 2 Multispectral Satellite}

Sentinel 2 was launched by European Space Agency (ESA) with two satellites (Sentinel 2-A and Sentinel 2-B). The temporal resolution is five days. The sensor is equipped with 10-meter four bands (red, green, blue, and near-infrared), six bands with a 20-meter spatial resolution (red edge and shortwave infrared band), and three bands with 60 -meter resolution (aerosols, water vapor, and cirrus) for earth observation [17]. In this study, 24 imageries from 2019 are collected from the month of February until December. Each month has a minimum of one image with a maximum cloud cover of 20 percent.

\subsubsection{Normalized Difference Vegetation Index (NDVI)}

The NDVI can be used as an indicator of plant greenness $[8,14,18]$. NDVI uses the calculation of near-infrared and red bands. The formula is as follows:

$$
N D V I=(N I R-R e d) /(N I R+R e d)
$$

\subsubsection{Normalized Difference Water Index (NDWI)}

The limitation for NDVI in rice crop identification is found in the early stages of paddy, where the rice is planted in inundated land [1] and had only a few leaves. Therefore the water index is needed to determine the early stages of rice [19]. Normalized difference water index (NDWI) [15] using near-infrared and middle infrared/shortwave infrared. The formula is as follows:

$$
N D W I=(N I R-S W I R) /(N I R+S W I R)
$$

\subsubsection{Planting Time and Harvesting Time with Thresholding Method}

To set the planting and harvesting time threshold value, this study using field data collection results and crosschecked with the previous study by Sari [12], Hernawati [20], and Lestari [21]. For phenological identification on the first step is analyzing the heading date $[12,20]$. Based on Lestari [21] range of NDVI value is $0.652-0.884$ in the last vegetative phase (include heading phase) about 60 days after planting [12]. And based on the field data result in 3.1, the threshold value at the heading phase for NDVI is 0.6. After heading phase identification, planting date identification is about 60 days past from heading phase. Spectral characteristic in planting time based on Sari [12] and Hernawati [20] NDWI/LSWI value is greater or equal with NDVI value. In harvesting time, from the field data result in 3.1 the NDVI value is 0.6. Based on Sari [12] and Hernawati [20] and field data result the NDWI/LSWI value is lower than the NDVI value. The framework of the thresholding method is in Fig 2. 


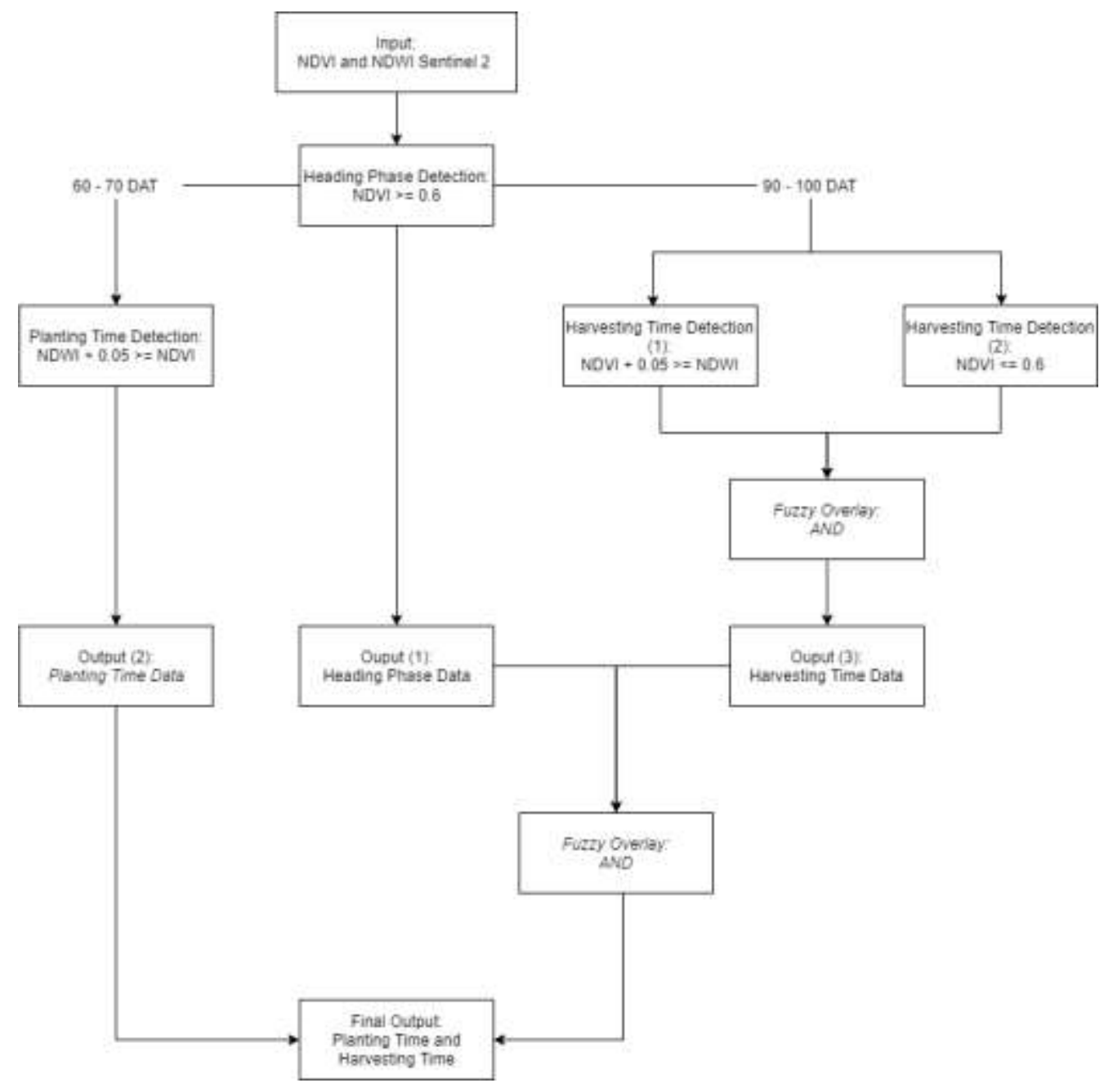

Fig 2. Rice Planting and Harvesting Time Thresholding Framework

\subsection{Field Data Acquisition}

Field data acquisition is conducted for collecting rice age and rice variety. The sampling method used for collecting data is purposive grid sampling, with \pm 100 sample considering the existence of the farmer, the accessibility to the rice field, and the variation of rice field growth phase. A field survey was held from 24 August 2020 until 27 August 2020.

\section{Result and Discussion}

\subsection{Rice Phenology Based on NDVI and NDWI Values}

NDVI always has a greater value than NDWI in each phase except land preparation. This is because of the background of the increasing crop canopy. Based on Fig 3., in the early phase of planting, farmers usually do some land preparation. In this stage, the rice crop is inundated, 
lead to the value of NDWI is greater than NDVI because water is saturating the crop in the satellite image. In the planting stage, the NDWI value is approaching the NDVI value. From the planting stage until the heading phase of the rice plant the value of NDVI is increasing until maximum. From the heading phase until harvesting the value of both NDVI and NDWI is decreasing because of crop canopy yellowing and draining of water in rice crop. Rice phenology based on Fig 3. Supported with the quadratic graph model based on Fig. 4. and Fig. 5. which the NDVI value always greater than the NDWI value in the same rice age. The special spectral characteristic in the heading phase, planting, and harvesting stage can be analyzed for the threshold of planting and harvesting time.

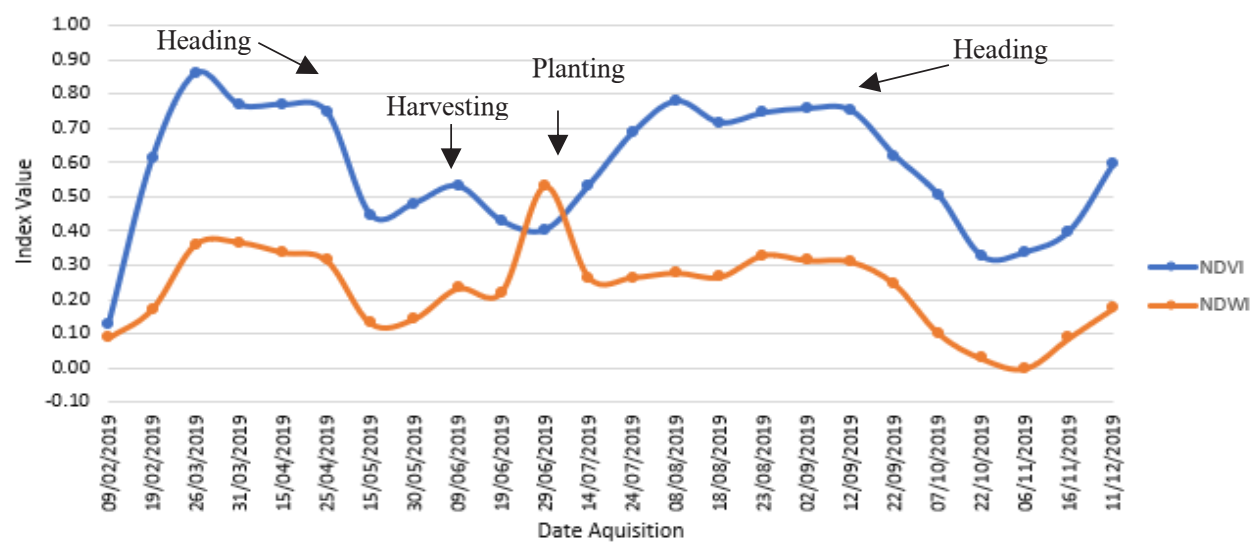

Fig.3 Rice Phenology Graph Based on Vegetation Index

The rice age model based on NDWI acquired from quadratic regression is in Fig. 4. resulting in the equation (3). Then, the rice age model based on NDVI acquired from quadratic regression is in Fig. 5. resulting in the equation (4). For equations (3) and (4), $X$ is the NDWI and NDVI value and $\mathrm{Y}$ is the estimated rice age. The $\mathrm{R}^{2}$ of the NDWI model is 0.14 with a significance of 0.02 with the RMSE of the model is 27 (days). For the NDVI model, the $\mathrm{R}^{2}$ is 0.24 with the significance of the model 0.00 with RMSE of the model is 17 (days). Based on $\mathrm{R}^{2}$ of both models, NDVI has better goodness of fit rather than NDWI with notes that rice field which hasn't planted yet (inundated) or in bare soil phase after harvested detected as an intolerable outlier and removed. But in NDWI value, some rice field with water background in tillage before transplantation isn't detected as on outlier which included for regression analysis. Therefore, the NDVI model in this study describing the rice field with only rice planted in it. Whereas the NDWI model describes the rice field from the tillage phase until rice is planted.

$$
\begin{gathered}
Y=-308.853 X^{2}+369.731 X-35.7 \\
Y=-231.765 X^{2}+212.857 X+
\end{gathered}
$$




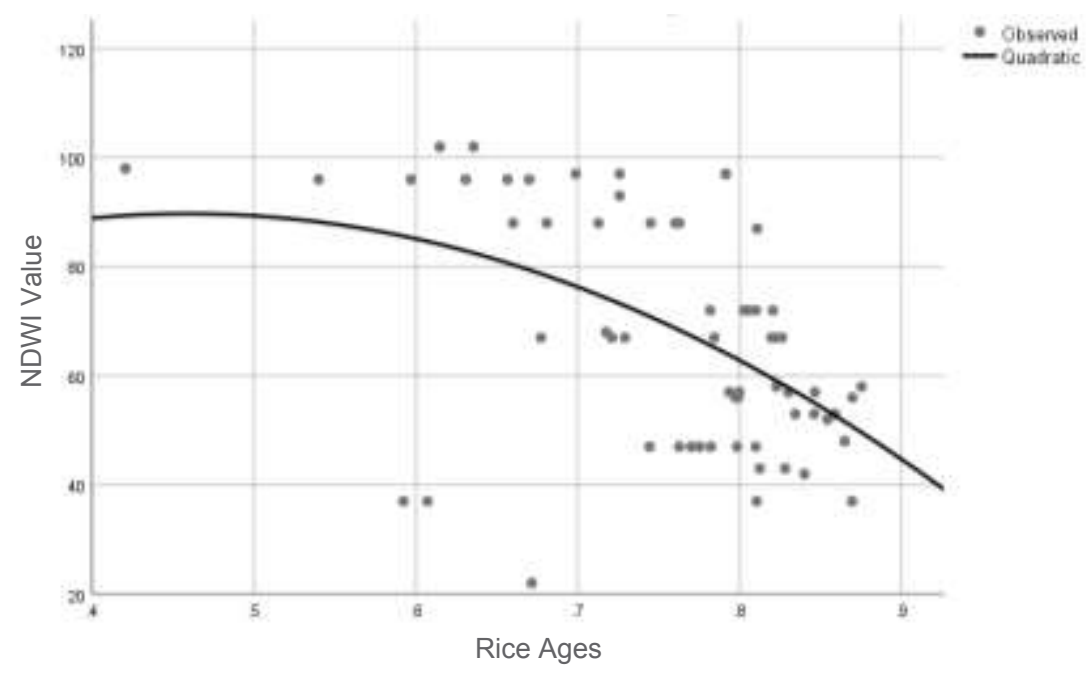

Fig 4. Rice Age Model Based on NDWI Value

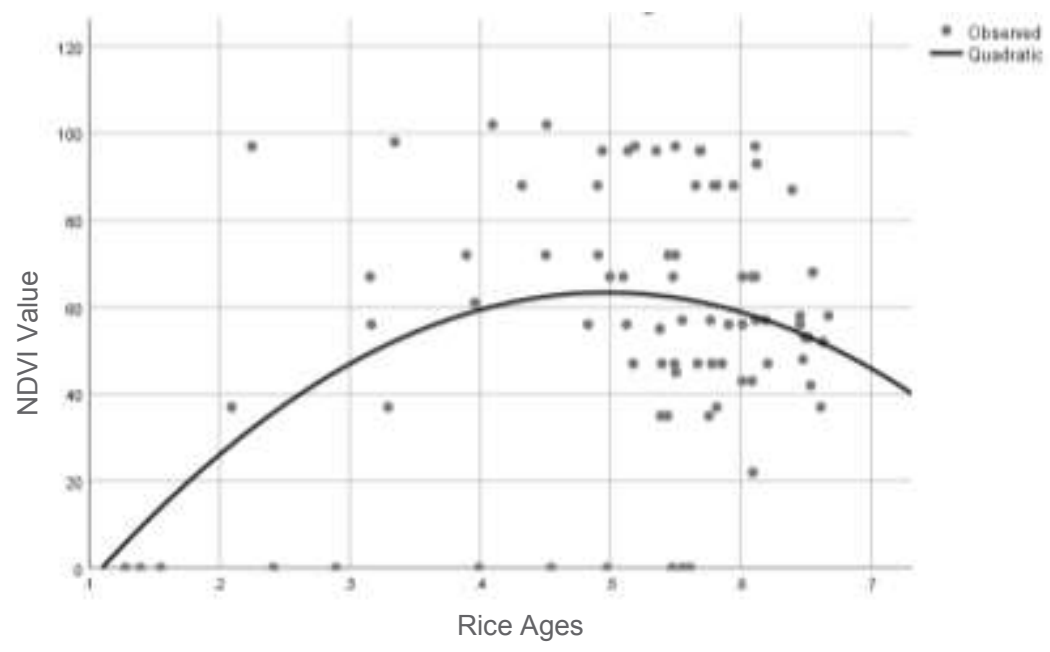

Fig 5. Rice Age Model Based on NDVI Value

\subsection{Value Distribution of NDVI and NDWI Based on Growth Phase}

In this study, Based on Fig. 6. the tendency of NDVI distribution value in planting time is mostly in the Q1 area with 0.12 value until the median with 0.22 value. While the NDWI, the tendency is mostly in Q1 with 0.12 value until median with 0.28 value. But Q3 of NDWI is higher than NDWI in 0.4 and the maximum value of NDWI is greater than the maximum NDVI value. From this, the planting time threshold concept is when the NDWI value is greater or the same as the NDVI value. 


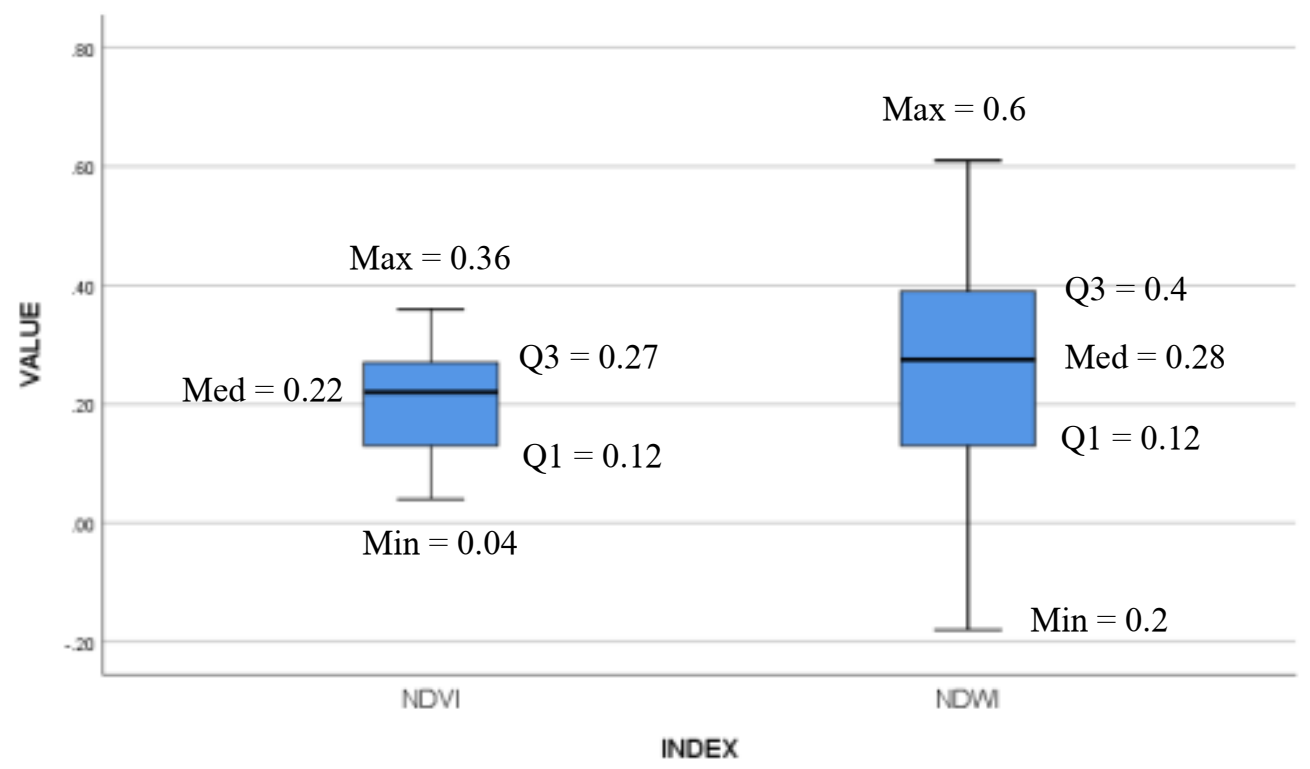

Fig. 6. Value Distribution in Planting Time

Based on Fig.7. the tendency of NDVI distribution value in the heading phase is mostly in the median area with 0.73 value until Q3 0.79 value. While the NDWI, the tendency is mostly in Q1 with 0.23 value until median with 0.29 value. Overall NDVI data is greater than NDWI even the outlier data of NDVI value is greater than the maximum value of NDWI. Based on Lestari [22] range of NDVI value in the heading phase is 0.652 until maximum value and from the field data, the NDVI toleratable outlier is 0.61 . From this, the NDVI value in the heading phase is more than 0.6 and the NDWI value is lower than NDVI.

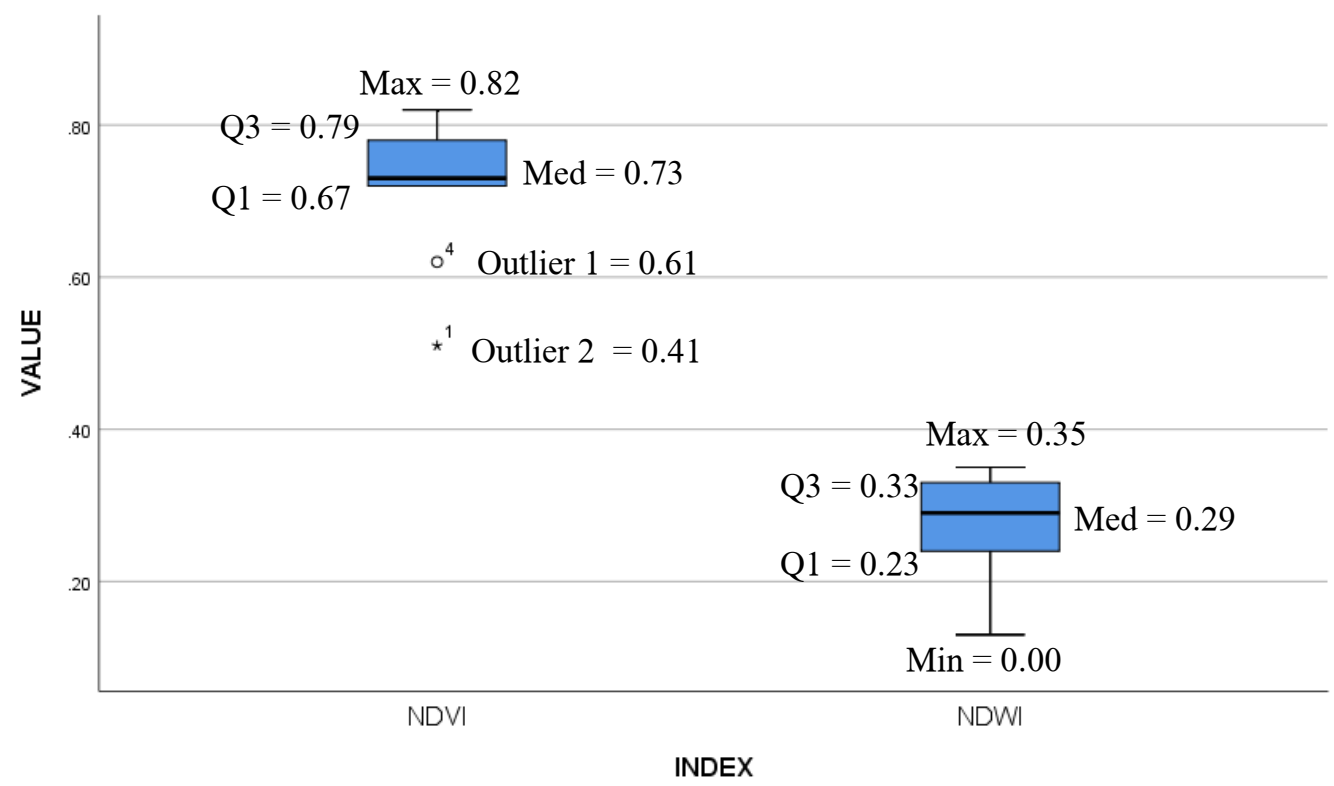

Fig. 7. Value Distribution in Heading Phase 
Based on Fig. 8. the tendency of NDVI distribution value in Harvesting time is mostly in the median area with 0.66 value until Q3 0.78 value. While the NDWI, the tendency is mostly in Q1 with 0.19 value until median with 0.3 value. Overall NDVI data is greater than NDWI, the maximum NDWI is equal to the toleratable outlier in 0.42 value for both indexes. Compared to the maximum value of NDVI in Fig. 7. the maximum value of NDVI in harvesting time is lower. Considering the value of the heading phase threshold, for the harvesting time, this study set the NDVI Value with 0.6 in the lower limit of Q1 as the harvesting time threshold. For the NDWI value, set lower than NDVI same as heading phase threshold. The reason this study set 0.6 as the value of harvesting time threshold, because below 0.6 NDVI value, most likely below that value, paddy has not reached the heading phase.

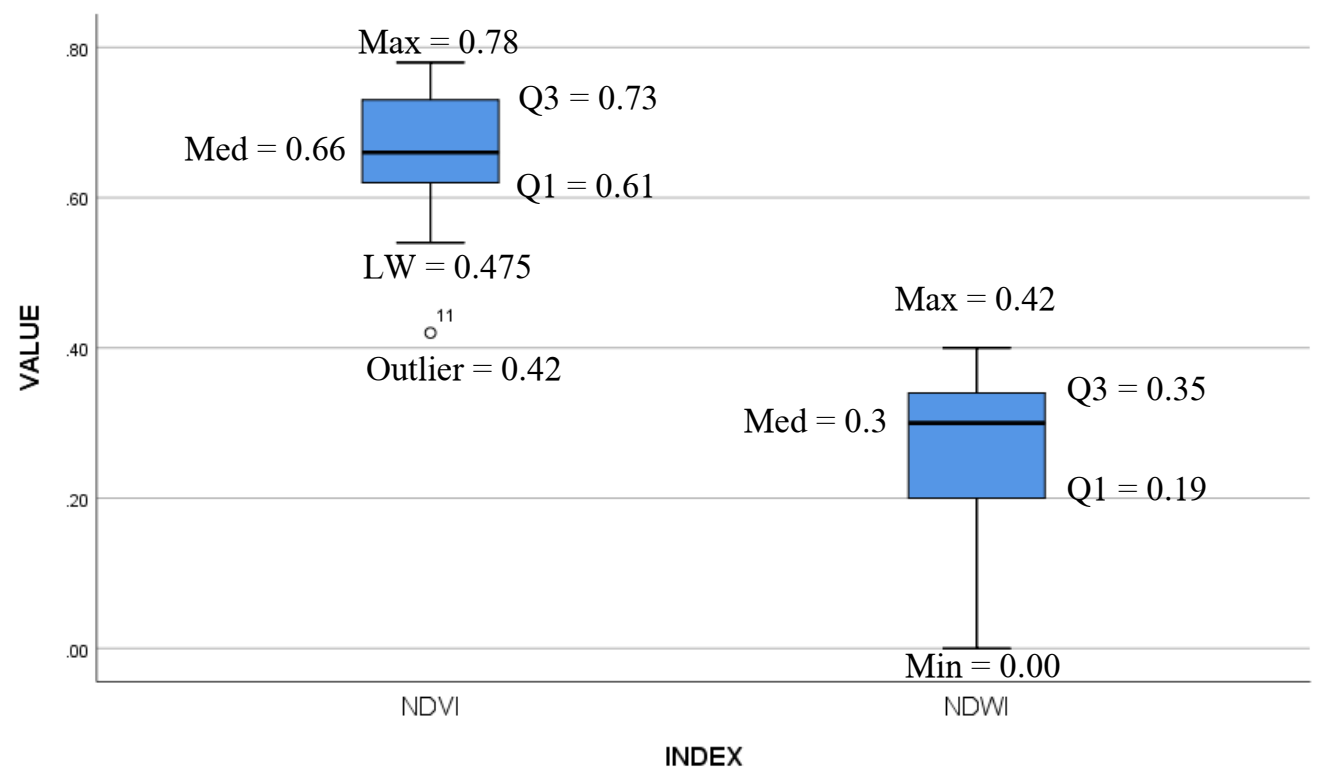

Fig. 8. Value Distribution in Harvesting Time

\subsection{Parakansalak 2019 Climate Condition}

Based on monthly rainfall 2018 and 2019 graph (Fig 4.), there is rainfall value decreasing between 2018 and 2019 in June, July, September, October, and November. In June 2019, the value of rainfall data is dropped from $184 \mathrm{~mm}$ to $2,96 \mathrm{~mm}$. And in September 2019, the value of rainfall data is dropped from $80,8 \mathrm{~mm}$ to $17,7 \mathrm{~mm}$. This can affect the rice planting season in Parakansalak. Local farmers also said that in 2019, in some rice crop areas, water discharge in some irrigation channels was decreased also caused by rainfall volume decreasing. Some irrigation that water discharge was decreased, rice crop area in lower elevation, were not watered, cause the water was infiltrated before reaching the rice crop area. 


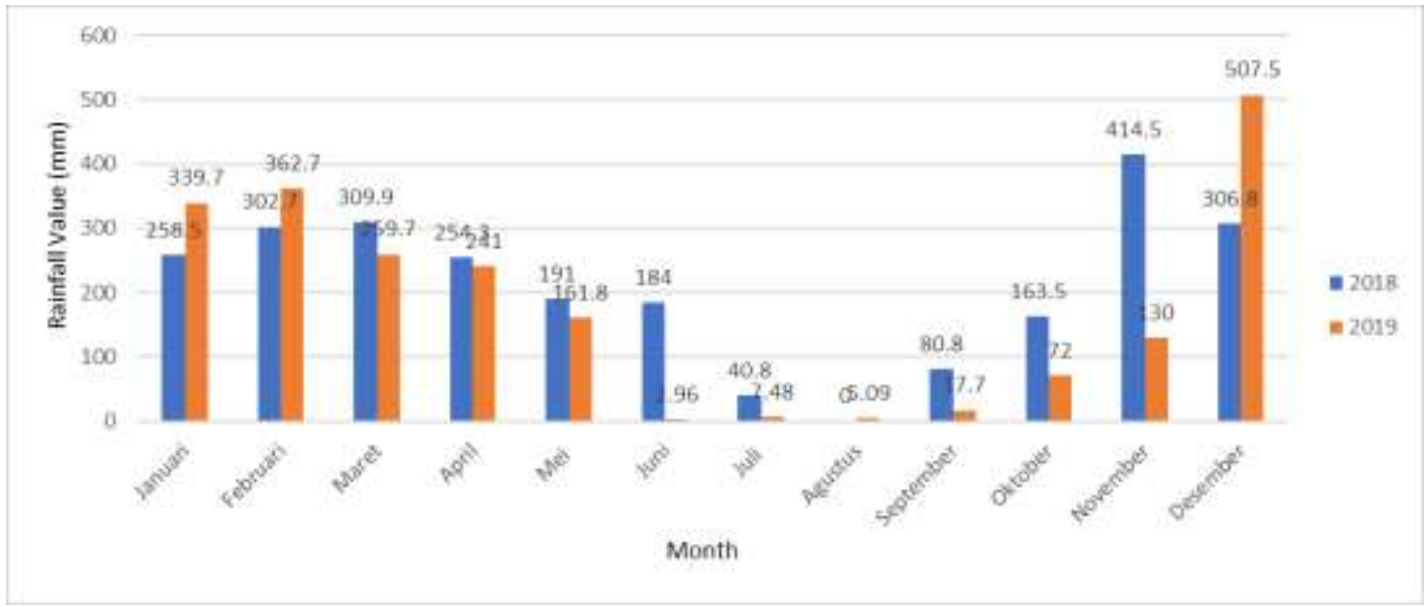

Fig. 4. 2018 and 2019 Monthly Rainfall Chart

\subsection{Overall Model Accuracy}

Fig. 5. and Fig. 6. is a comparison graph between estimation and tabular data of planting and harvesting area from BPP Parakansalak. The result shows that the root mean square error (RMSE) between tabular and estimation data is 145.37 hectares. June is the highest estimation in planting area with 145 hectares and the lowest planting area estimation is in October with 17 hectares. Then, in the harvesting area, the root mean square error (RMSE) between tabular and estimation data is 90,9 hectares. The highest harvesting area estimation is in February with 289 hectares, overestimated then tabular data because no crosschecking with fuzzy overlay with heading phase in January. In January there are no available satellite images with clear visibility. The lowest harvesting area estimation is in April with 32 hectares. The estimation of harvesting time area is higher compared with the estimation of planting.

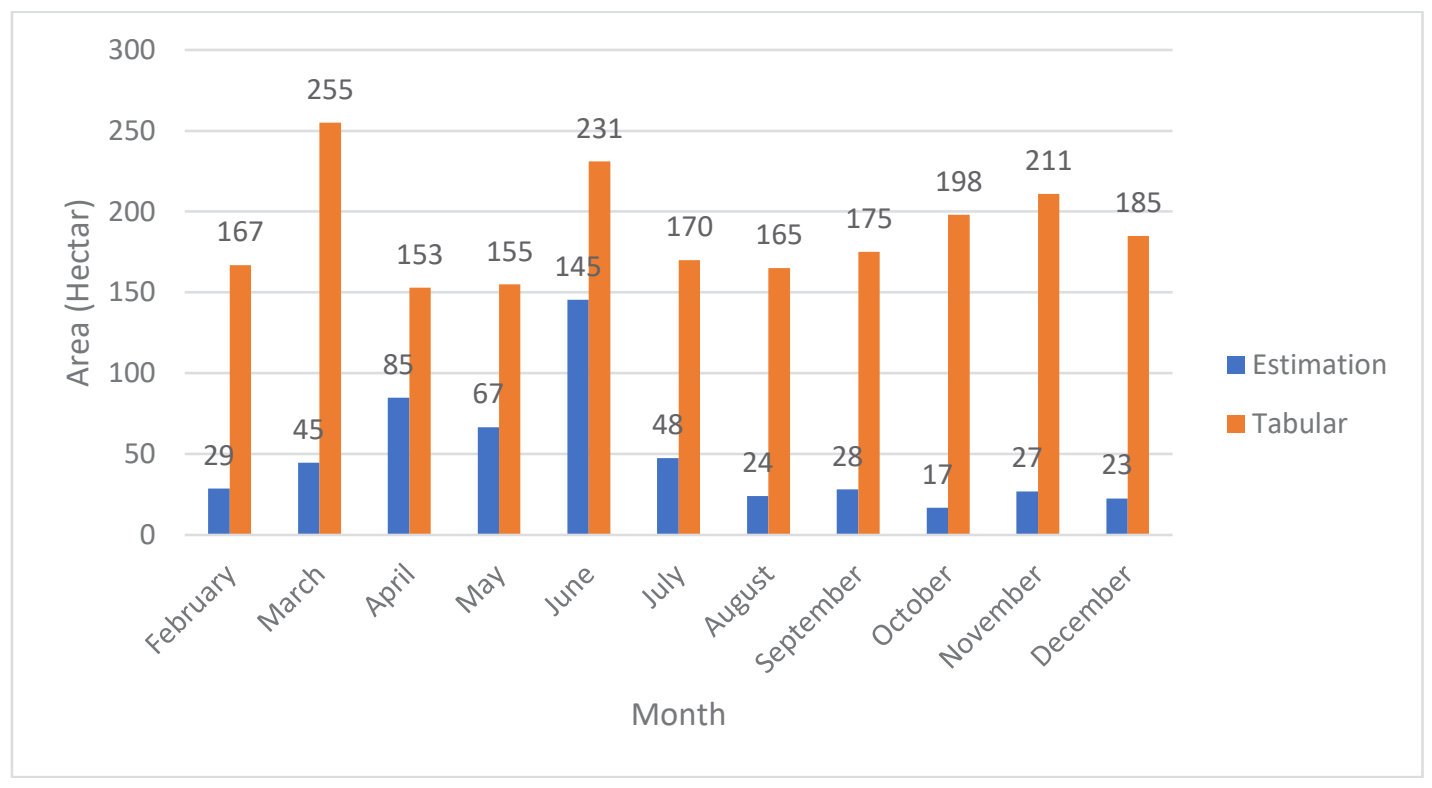


Fig. 5. 2019 Monthly Planting Area Estimation and Tabular Data

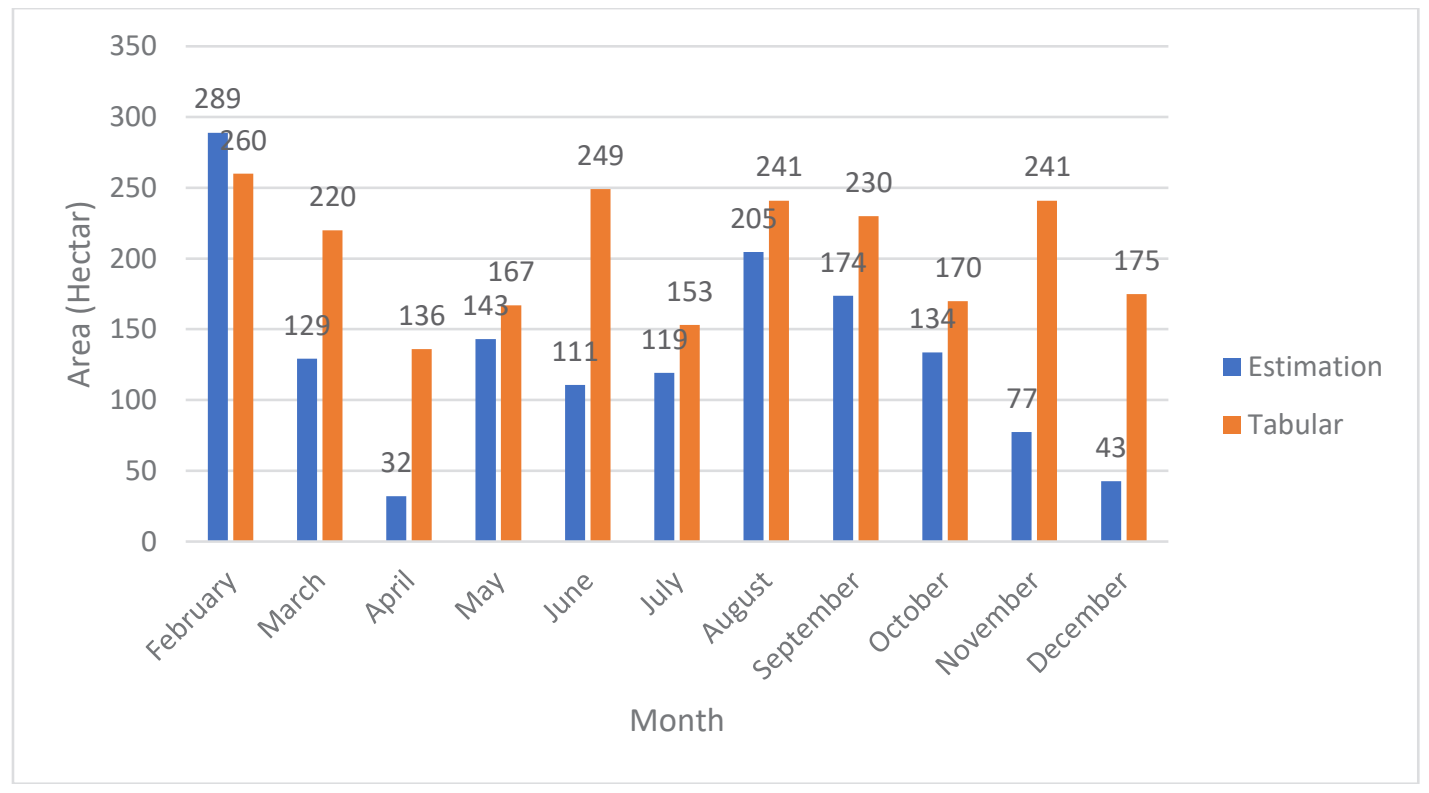

Fig. 6. 2019 Monthly Harvesting Area Estimation and Tabular Data

\subsection{Dry Season Planting and Harvesting Time}

Head of Parakansalak Agricultural Counselling Agency (BPP) argued that in Parakansalak there are two farming seasons, the first one is the dry season from April - September, and the second one is the wet season from October - March (in the next following year. From Fig. 5. and Fig. 6. farmers' tendency to start planting rice is in April, May, June and start to do harvesting in July for planting in April, August for planting in May, and September for planting in June. Related to the climate, June, July, August, and September are on dry month status with monthly total rainfall below $50 \mathrm{~mm}$, critically, it ranges from 2 until 17 which is suitable when local farmers do some harvesting, but not enough water supply for rice planting after harvesting in August or September.

On the village scale, the biggest total area of planting based on thresholding method within April, May, and June is Bojonglonggok village with 69.04 hectares total and with average planting area in April, May, and June is 23.01 hectares. The lowest area of planting area within April, May, and June is Lebaksari village with 31.06 hectares total with an average planting area is 10.35 hectares. For another village, the average planting area in Bojongasih village is 17.10 hectares, Parakansalak village is 19.16 hectares, Sukakersa village is 17.17 hectares and Sukatani village is 12.19 hectares. Based on rice age in thresholding assumption, if rice field planted in April, the harvest will happen in July, then if rice field planted in May, the harvest will happen in August, and if rice field planted in June the harvest will happen in September.

Within July, August, and September, the biggest harvesting area based on the thresholding method is Sukakersa village with a total harvested area is 115.74 hectares and 
the average harvested area is 38.58 hectares. The lowest harvesting area based on the thresholding method is Lebaksari village with a total harvested area of 51.36 hectares with the average harvesting area is 17.12 hectares. For another village, the average planting area in Bojongasih village is 26.34 hectares, Bojonglonggok village is 27.62 hectares, Parakansalak village is 22.68 hectares, and Sukatani village is 33.34 hectares.
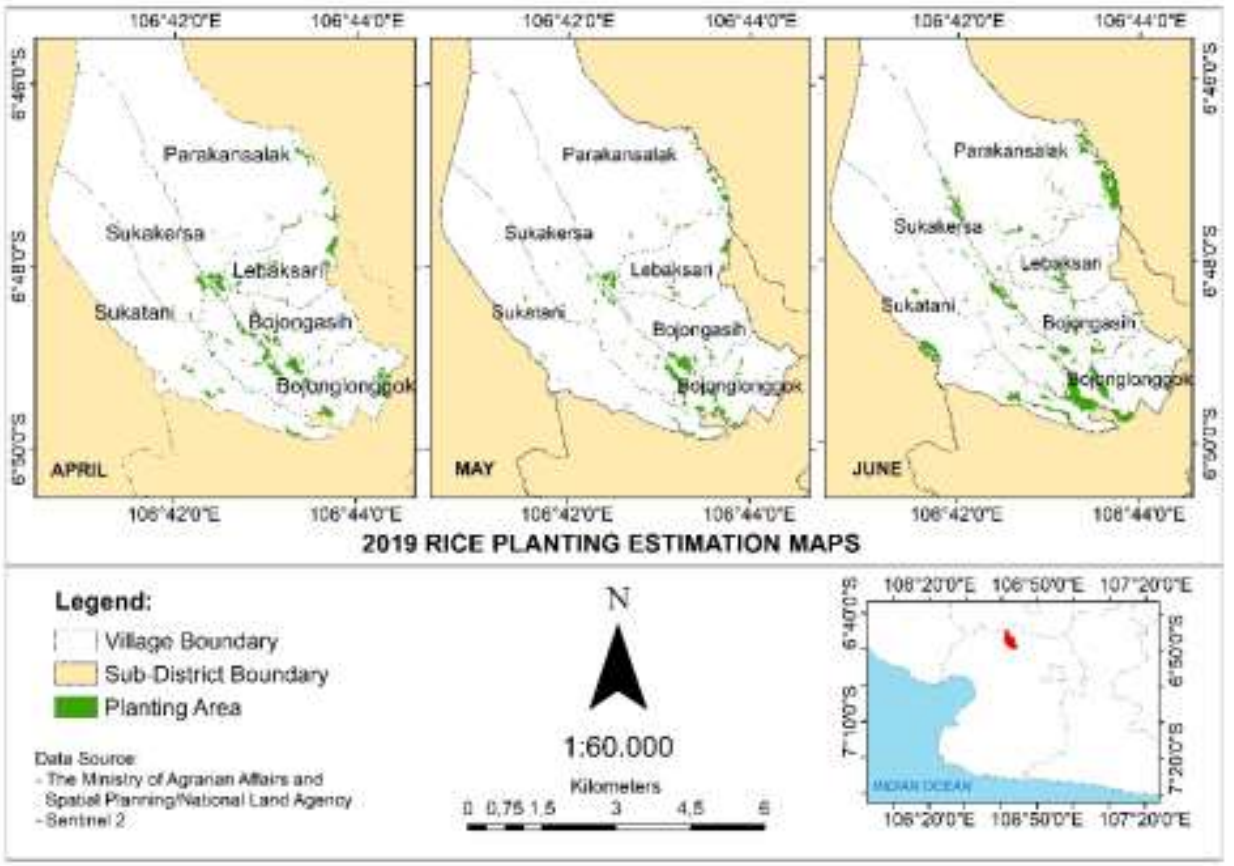

Fig 6. April, May, June 2019 Rice Planting Area
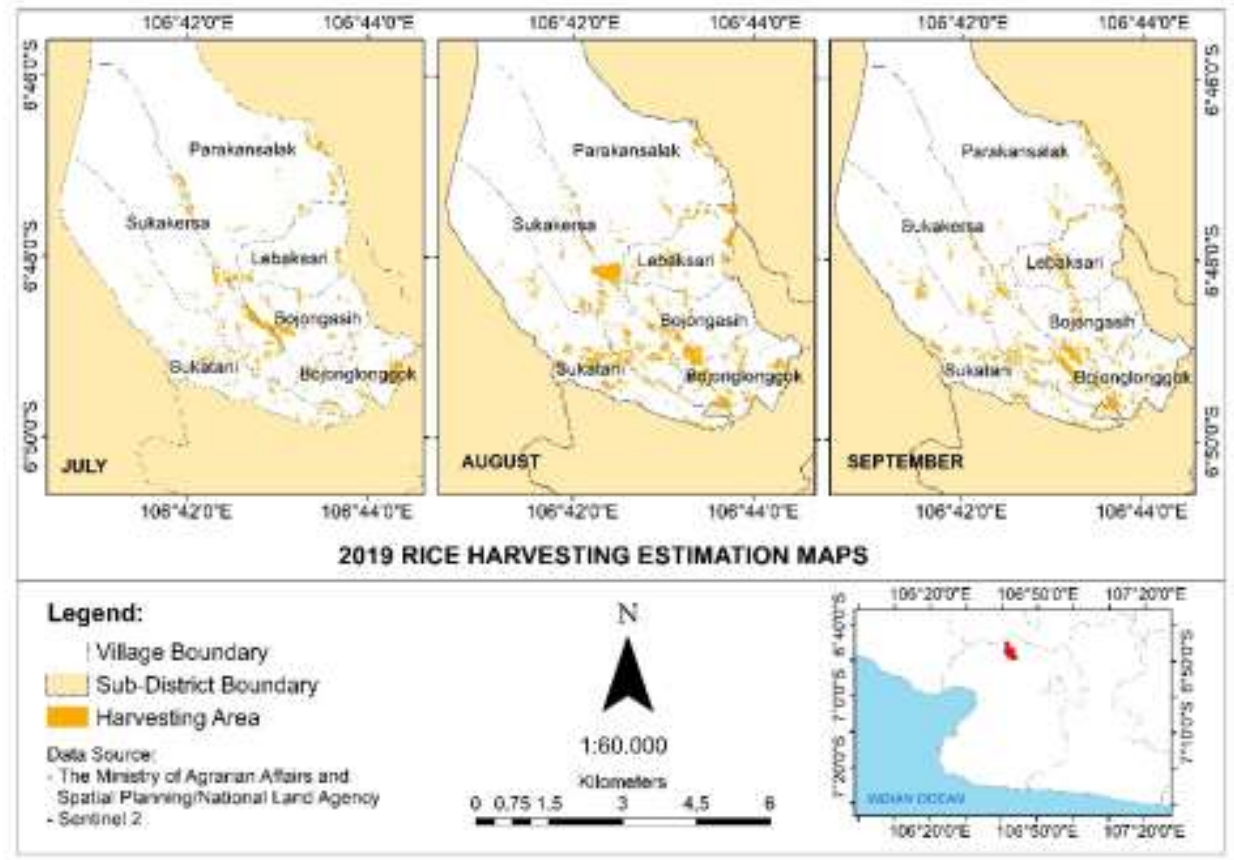

Fig 7. July, August, September 2019 Rice Harvesting Area 
For the next three months, the biggest total area of planting based on thresholding method within July, August, and September is Sukakersa village with 24.72 hectares total and with average planting area in April, May, and June is 8.24 hectares. The lowest area of planting area within April, May, and June is Lebaksari village with 2.88 hectares total with the average planting area is 0.96 hectares. For another village, the average planting area in Bojongasih village is 3.70 hectares, Bojonglonggok village is 7.40 hectares, Parakansalak village is 7.64 hectares, Sukatani village is 5.32 hectares. Based on rice age in thresholding assumption, if rice field planted in July, the harvest will happen in October, then if rice field planted in August, the harvest will happen in November, and if rice field planted in September the harvest will happen in December.

Within October, November, and December, the biggest harvesting area based on the thresholding method is Bojonglonggok village with a total harvested area is 59.24 hectares and the average harvested area is 19.75 hectares. The lowest harvesting area based on the thresholding method is Lebaksari village with a total harvested area of 15.45 hectares with the average harvesting area is 5.5 hectares. For another village, the average planting area in Bojongasih village is 9.97 hectares, Parakansalak village is 15.29 hectares, Sukakersa village is 17.76 , and Sukatani village is 16.60 hectares.

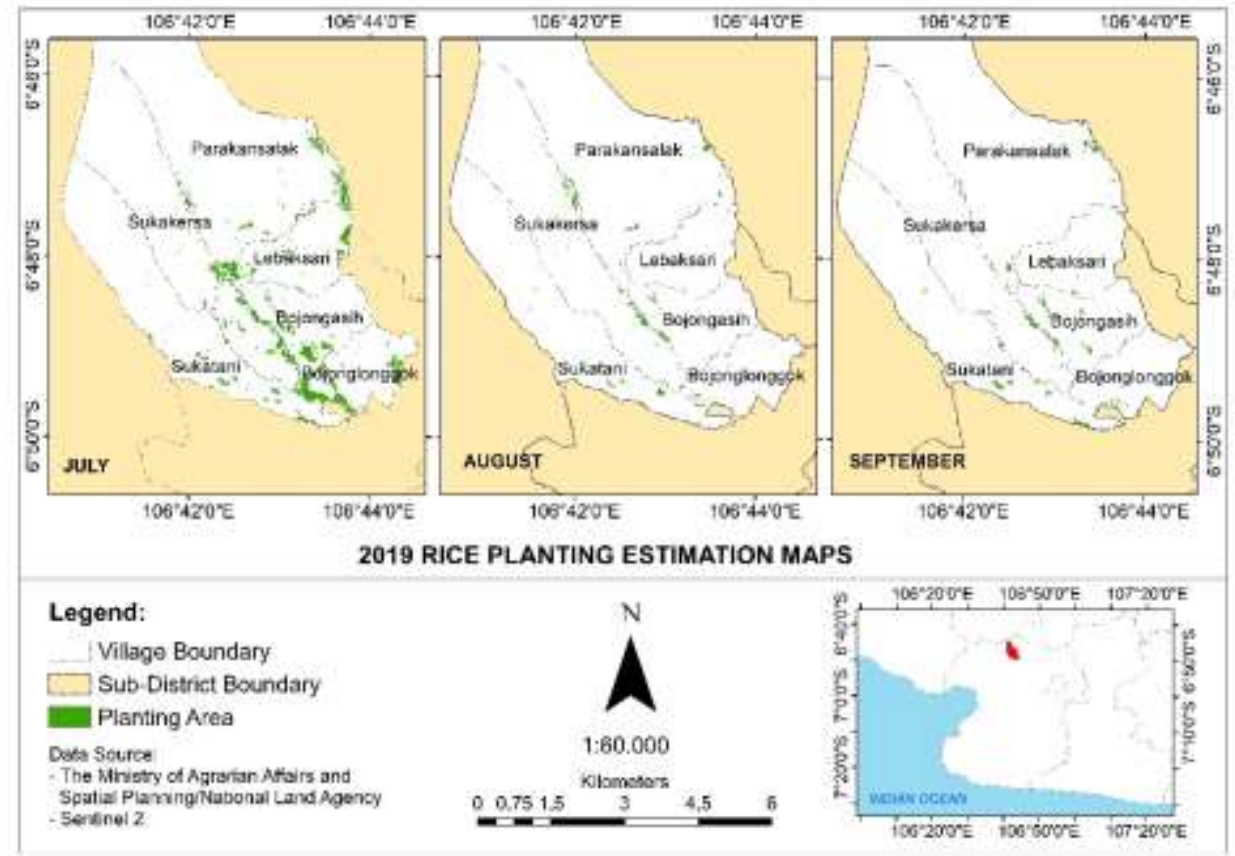

Fig 8. July, August, September 2019 Rice Planting Area 


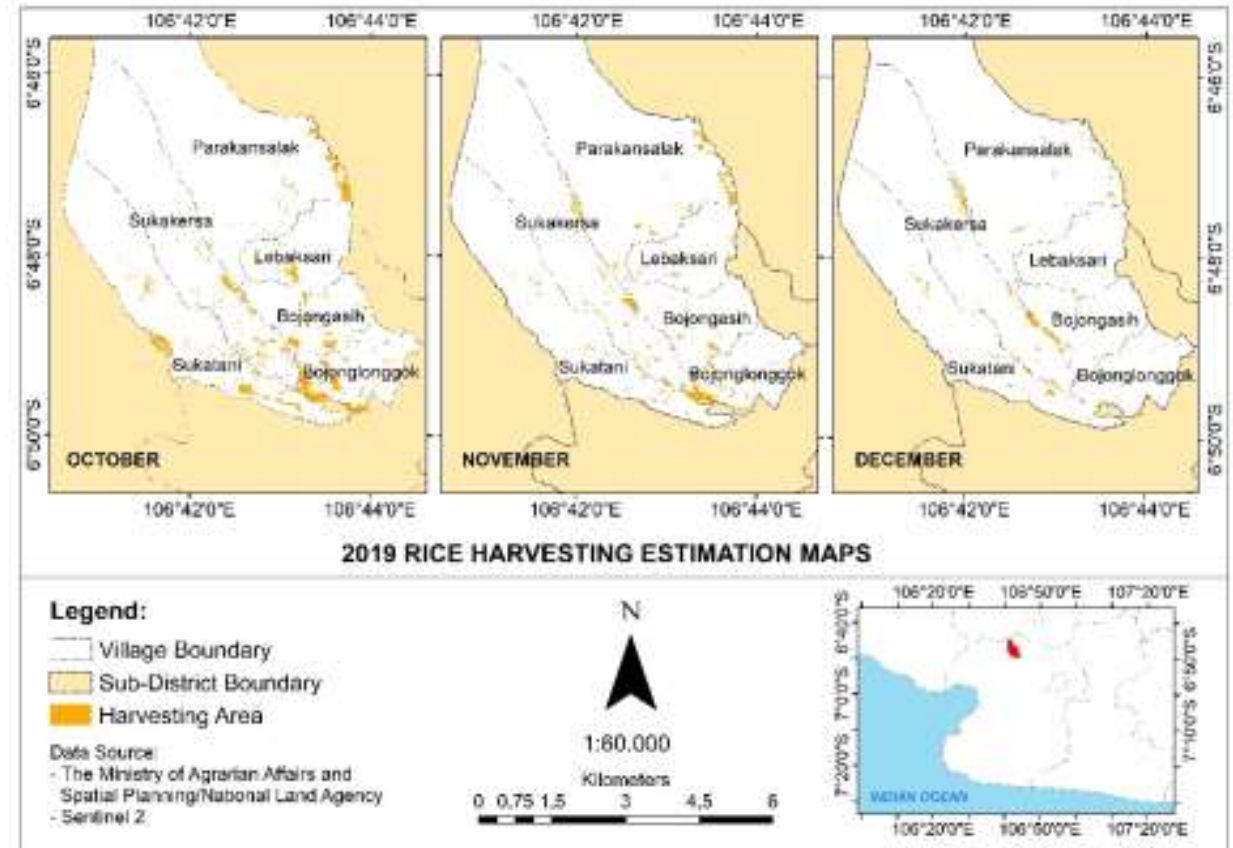

Fig 9. July, August, September 2019 Rice Planting Area

\section{Conclusion}

The model of the rice phenology based on NDVI and NDWI has a moderate result with greater $\mathrm{R}^{2}$ in NDVI than NDWI. In partial value distribution, for heading phase and harvesting time, the value of NDVI is concentrated in a small range of data, and easier to deciding the value threshold for estimating the harvesting time if another index is used. Based on the result of estimated rice planting time and harvesting time with thresholding method using Sentinel 2 satellite, the estimation of harvesting time has more suitable result than planting time with lower RMSE value with the monthly tabular data from BPP Parakansalak. If the tabular data is in daily unit, it is possible to know the exact result of the threshold model cause of the limitation of Sentinel 2 images towards cloud cover or the result will more accurate if the same method is applied in radar remote sensing.

\section{References}

1. J. Dong and X. Xiao, ISPRS J. Photogramm. Remote Sens. 119, 214 (2016).

2. B. Bua and M. Ojirot, Am. J. Exp. Agric. 4, 532 (2014).

3. Kementerian Pertanian, Buletin Konsumsi Pangan 2019 (2018).

4. K. Moldenhauer, P. Counce, and J. Hardke, in Rice Prod. Handbook, Univ. Arkansas (University of Arkansas, Arkansas, 2018), pp. 9-20.

5. D. J. Greenland, The Sustainability of Rice Farming (CAB International in Association with IRRI, Wallingford, 1977).

6. IRRI, Step to Successful Rice Production (2015).

7. Rokhmatuloh, Supriatna, A. Wibowo, and I. P. A. Shidiq, Int. J. GEOMATE 19, 205 (2020). 
8. A. Yudono, Geoplanning J. Geomatics Plan. 5, 131 (2018).

9. M. S, K. SH, K. Zarkesh M, D. F, and A. Safaval P, J. Geogr. Nat. Disasters 08, 1 (2018).

10. Supriatna, Rokhmatuloh, A. Wibowo, I. P. A. Shidiq, G. P. Pratama, and L. Gandharum, Int. J. GEOMATE 17, 101 (2019).

11. K.-W. Chang, Y. Shen, and J.-C. Lo, Agron. J. 97, 872 (2017).

12. 2. D. K. Sari, I. H. Ismullah, W. N. Sulasdi, and A. B. Harto, ITB J. Sci. 42 A, 91 (2010).

13. L. Wang, F. C. Zhang, Y. S. Jing, X. D. Jiang, S. Bin Yang, and X. M. Han, Rice Sci. 21, 108 (2014).

14. J. W. Rouse, R. H. Haas, J. A. Schell, and D. W. Deering, in Goddard Sp. Flight Cent. 3d ERTS-1 Symp. (NASA, Texas, 1974), pp. 309-317.

15. B. Gao, 266, 257 (1996).

16. M. Jia, Z. Wang, C. Wang, D. Mao, and Y. Zhang, Remote Sens. 11, 1 (2019).

17. 17. A. Taufik, S. S. Syed Ahmad, and E. F. Azmi, Lect. Notes Networks Syst. 67, 275 (2019).

18. H. Yin, T. Udelhoven, R. Fensholt, D. Pflugmacher, and P. Hostert, Remote Sens. 4, 3364 (2012).

19. K. Chandrasekar, M. V. R. Sesha Sai, P. S. Roy, and R. S. Dwevedi, Int. J. Remote Sens. 31, 3987 (2010).

20. R. Hernawati, A. B. Harto, and D. K. Sari, Reka Geomatika J. Tek. Geod. Dan Geomatika 2017, 91 (2017).

21. E. A. P. Lestari, Supriatna, and A. Damayanti, in Life Environ. Sci. Acad. Forum 2018 (IOP Science, 2020). 